\title{
Immunologisk trombocytopeni - patofysiologi og behandling
}

\begin{abstract}
Sammendrag
Bakgrunn. Trombocytopeni forårsaket av immunmediert trombocyttdestruksjon og nedsatt trombocyttproduksjon kalles immunologisk trombocytopeni (ITP). Formålet med denne artikkelen er å gi en oppdatering omkring patofysiologi og behandling av sykdommen.
\end{abstract}

Materiale og metode. Artikkelen er basert på ikke-systematisk litteraturs $ø$ k i PubMed og egne kliniske erfaringer.

Resultater. Diagnosen immunologisk trombocytopeni settes hos pasienter med blodplatetall $<100 \cdot 10^{9} / \mathrm{l}$ der det ikke er andre årsaker til trombocytopenien. Autoantistoffer mot trombocytter er en sentral mekanisme ved platedestruksjonen, men de siste årene har andre mekanismer også vist seg å være av betydning. Pasienter med svært lavt blodplatetall (<30 $10 \% /$ l) er spesielt utsatt for blødningskomplikasjoner. Målet med behandlingen er å øke blodplatetallet til et nivå der risikoen for alvorlig blødning er redusert. Behandlingsstrategien har frem til nå vært å forlenge trombocyttlevetiden - enten ved medikamentell immunsuppresjon eller splenektomi. Trombopoietinreseptoragonister er nye medikamenter som øker blodplateproduksjonen ved å stimulere trombopoietinreseptorene. Det har vist seg at disse midlene er effektive behandlingsalternativer ved immunologisk trombocytopeni.

Fortolkning. Ny kunnskap om patofysiologiske mekanismer som suboptimal trombocyttproduksjon har åpnet for nye terapeutiske muligheter der man legger hovedvekten på stimulering av blodplateproduksjonen.

\section{Waleed Ghanima*}

waleed.ghanima@so-hf.no

Hematologisk seksjon

Medisinsk avdeling

Sykehuset Østfold Fredrikstad

1603 Fredrikstad

\section{Pål André Holme}

Avdeling for blodsykdommer

Oslo universitetssykehus

\section{Geir E. Tjønnfjord}

Avdeling for blodsykdommer Oslo universitetssykehus

og

Institutt for klinisk medisin

Universitetet i Oslo

\section{* Nåværende adresse:}

Division of pediatric hematology oncology

Weill Cornell medical college, New York, USA

Immunologisk trombocytopeni (ITP), tidligere benevnt «idiopatisk trombocytopenisk purpura», er trombocytopeni forårsaket av immunmediert destruksjon av trombocyttene. Trombocytopenien medfører ofte, men ikke alltid, økt risiko for blødning (1).

En internasjonal arbeidsgruppe publiserte nylig et forslag til nye definisjoner og diagnostiske kriterier for sykdommen. Gruppen foreslo også en navnendring - «idiopatisk» endres til «immunologisk» og «purpura» fjernes, fordi slett ikke alle pasienter har blødninger. Man ønsket imidlertid å beholde det godt innarbeidede akronymet ITP som forkortelse for den nye benevnelsen også. Den viktigste endringen når det gjelder diagnostikk er at kravet til trombocytopeni skjerpes fra trombocyttall $<150 \cdot 10^{9} / 1$ til $<100 \cdot 10^{9} / 1(2)$. Ytterligere definisjoner og kriterier finnes i tabell 1. Insidensen av immunologisk trombocytopeni hos voksne er anslått å ligge på $1-4$ per $100000(3,4)$, prevalensen på 9,5/100 000 (5).

Formålet med denne artikkelen er å gi en oversikt over sykdommens patofysiologi og behandling.

\section{Materiale og metode}

Artikkelen er basert på et ikke-systematisk litteratursøk i PubMed og egne kliniske erfaringer.

\section{Patofysiologi}

Immunologisk trombocytopeni er en autoimmun sykdom hvor trombocyttlevetiden er redusert pga. immunmediert destruksjon av trombocytter (fig 1). Antistoffene binder seg til overflateantigenene glykoprotein (GP) IIb-IIIa eller GPIb-IX (6). Blodplater med slike autoantistoffer bundet til overflaten blir fjernet fra sirkulasjonen ved fagocytose i det retikuloendoteliale systemet. Nyere forskning har avdekket et mer komplisert bilde med T-celleinteraksjon og nedsatt plateproduksjon (fig 1). B-cellenes produksjon av antitrombocyttantistoffer er avhengig av antigenspesifikke CD4-positive T-celler (T-hjelpeceller) (7). Pasientene har ofte en cytokinprofil forenlig med CD4-positiv Th0/Th1aktivering og på samme tid nedsatt nivå av Th2-celler og regulatoriske T-celler, som normalt forhindrer aktivering og proliferasjon av autoreaktive T-lymfocytter (8). In vitro-eksperimenter har vist at cytotoksiske T-celler fra pasienter med immunologisk trombocytopeni kan indusere trombocytt- og muligens megakaryocyttdestruksjon (8-10).

Det er vist at trombocyttproduksjonen er suboptimal ved immunologisk trombocytopeni som følge av redusert megakaryocyttmodning og økt apoptose av megakaryocyttene (11). Trombocytopoesen er kontrollert av blant annet endogent trombopoietin (TPO) (12). Normalt stiger TPO-nivået når blodplatetallet faller, f.eks. ved aplastisk anemi og kjemoterapiindusert trombocytopeni. Ved immunologisk trombocytopeni er det imidlertid normale eller lave TPO-nivåer (13). Dette indikerer at sykdommen er karakterisert ved redusert trombocyttlevetid og samtidig suboptimal trombocyttproduksjon. Denne kunnskapen har åpnet for nye terapeutiske muligheter der man legger vekt på stimulering av blodplateproduksjonen.

\section{Diagnostikk}

Immunologisk trombocytopeni rammer både barn og voksne, og diagnosen bør mistenkes hos pasienter med blodplatetall under $100 \cdot 10^{9} / 1$. Blødningsmanifestasjoner ses vanligvis først ved blodplatetall under

\section{Hovedbudskap}

- Karakteristisk for immunologisk trombocytopeni er immunmediert trombocyttdestruksjon og samtidig suboptimal trombocyttproduksjon

- Trombopoietinreseptoragonister er nye, effektive medikamenter som virker gjennom stimulering av blodplateproduksjonen 
Tabell 1 Ny klassifikasjon og stadieinndeling av immunologisk trombocytopeni (ITP), utarbeidet av den internasjonale arbeidsgruppen for sykdommen (2)

\section{Betegnelse}

Primær immunologisk trombocytopeni

Sekundær immunologisk trombocytopeni

Nydiagnostisert immunologisk trombocytopeni

Persisterende immunologisk trombocytopeni

Kronisk immunologisk trombocytopeni

Refraktær immunologisk trombocytopeni

Alvorlig immunologisk trombocytopeni

\section{Definisjon}

Isolert trombocytopeni (trombocyttall $<100 \cdot 10^{9} /$ l) i fravær av andre årsaker til immuntrombocytopeni

Immunmediert trombocytopeni forårsaket av underliggende sykdom som lupus erythematosus, kronisk lymfatisk leukemi, virusinfeksjoner (hiv, hepatitt C-virus, cytomegalovirus) eller medikamenter (valproat, kinin/kinidin, østrogener)

Immunologisk trombocytopeni de første tre månedene etter diagnose

Manglende remisjon (spontant eller etter behandling) eller tilbakefall etter seponering av behandlingen 3-12 måneder etter diagnose

Vedvarende immunologisk trombocytopeni i mer enn 12 måneder etter diagnose

To kriterier må være oppfylt:

- Manglende respons etter splenektomi eller residiv etter splenektomi

- Alvorlig immunologisk trombocytopeni med risiko for blødninger, som derfor krever behandling

Alvorlig immunologisk trombocytopeni er definert ved blødninger som krever behandling
$30 \cdot 10^{9} / 1$. Det kliniske bildet kan variere fra tilfeldig påvist trombocytopeni hos en asymptomatisk pasient til milde hud- og/ eller slimhinneblødninger og til slutt til mer alvorlige blødninger i gastrointestinaltractus og sentralnervesystemet.

Dette er en eksklusjonsdiagnose. Det er helt avgjørende for diagnostiseringen at andre årsaker til lavt blodplatetall er utelukket (tab 1). Diagnosen er basert på kliniske funn, blodcelletellinger og vurdering av blodutstryk. Beinmargsundersøkelse anses ikke som nødvendig for å stille diagnosen hos personer under 60 år med isolert trombocytopeni. Slik undersøkelse bør derimot utføres hos dem som har tegn på andre cytopenier - for å utelukke tilstander som myelodysplastisk syndrom, ved manglende effekt av førstelinjebehandling og før splenektomi (14). Påvisning av autoantistoffer har høy spesifisitet, men lav sensitivitet. Dette betyr at en negativ test ikke utelukker immunologisk trombocytopeni. Påvisning av antistoffer har dessuten vanligvis ikke praktisk betydning, derfor anbefales det ikke å utføre testen rutinemessig (14). Det kan dog være nyttig å teste for antistoffer ved uavklart trombocytopeni, ved mistanke om medikamentassosiert immunologisk trombocytopeni eller når man mistenker koeksisterende immunmediert trombocytopeni med beinmargssvikt (6).

Mortalitet, morbiditet, og livskvalitet En systematisk gjennomgang som omfattet 17 pasientserier, til sammen 1817 personer med blodplatetall $<30 \cdot 10^{9} / 1$, viste klar sammenheng mellom alder og blødningsrisiko (15). Den aldersjusterte forekomsten av fatal blødning økte fra $0,4 \%$ hos dem $<40$ år til $13 \%$ hos dem $>60$ år. En ny studie fra England viste signifikant høyere mortalitet for pasienter med immunologisk trombocytopeni - 1,6 - sammenliknet med aldersmatchede kontrollpersoner (4), men litteraturen er ikke entydig når det gjelder risikoen for blødning og blødningsrelatert mortalitet ved denne sykdommen (1).
Immunologisk trombocytopeni har først og fremst vært oppfattet som en blødningstilstand. Imidlertid viser nye studier at pasientene har nedsatt livskvalitet, og at livskvaliteten er dårligere enn hos mennesker med andre kroniske sykdommer som hypertensjon, artritt og kreft (16). Opp mot 90\% klager over fatigue, som er hemmende i dagliglivet (17). Angst, depresjon og søvnløshet er rapport hos over $50 \%$.

\section{Behandling}

Behandlingsmålet er å øke blodplatetallet til et nivå der risikoen for alvorlig blødning minimeres (2). Risikoen for behandlingsrelaterte bivirkninger er stor, derfor må beslutning om behandling veies mot risikoen for blødning (18). Komorbiditet som uremi, leversykdom, alkoholmisbruk, dårlig kontrollert hypertensjon og bruk av medikamenter som hemmer blodplatefunksjonen gir økt

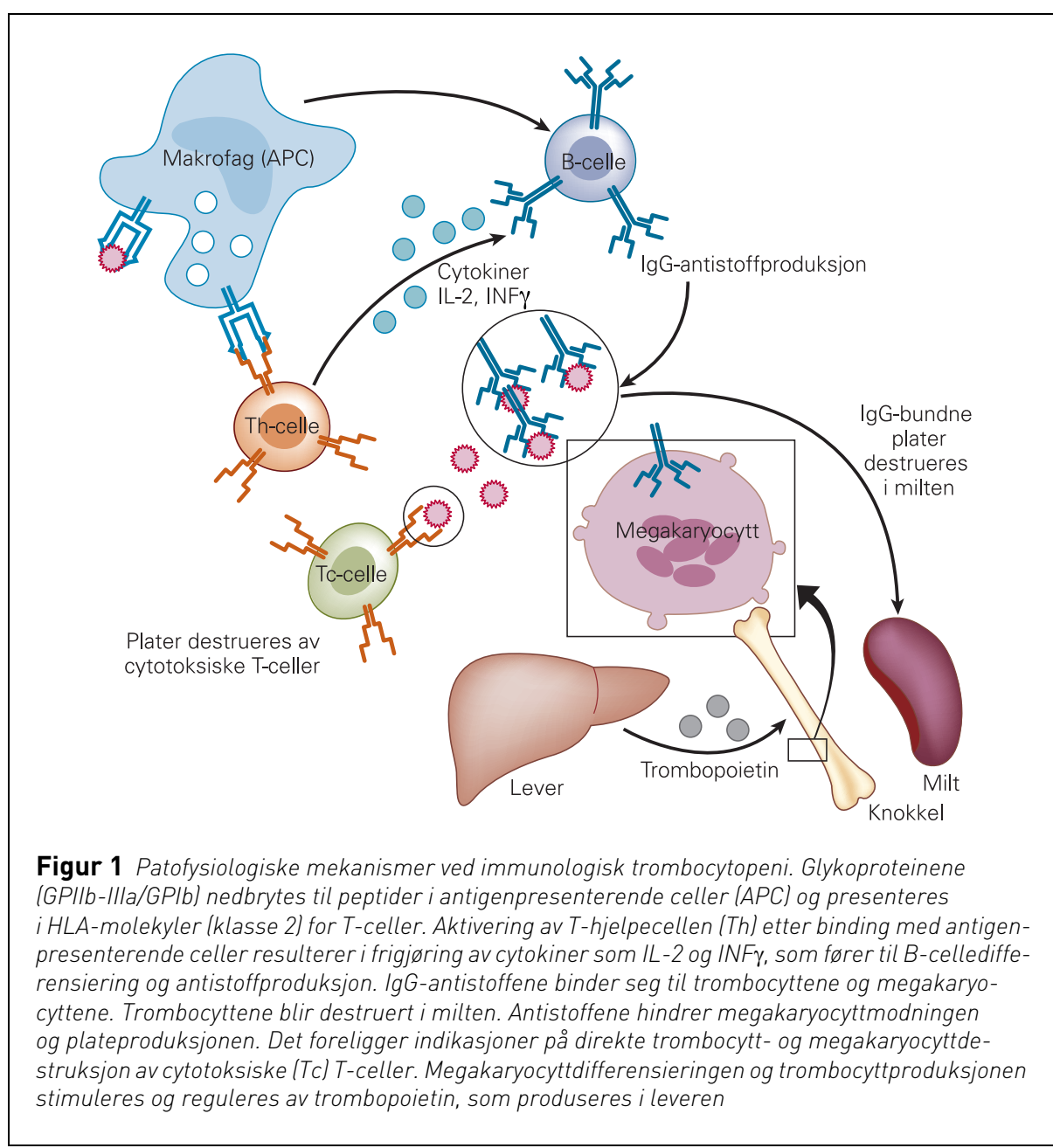


risiko for blødning. Det må tas hensyn til livsstil, pasientens arbeidssituasjon og vedkommendes synspunkter når beslutning om behandling skal tas. Hver gang ny behandling overveies iverksatt bør det gjøres en ny vurdering der blødningsrisikoen veies opp mot bivirkningene. Gjeldende internasjonale retningslinjer anbefaler behandling kun hos dem med platetall $<30 \cdot 10^{9} / 1$ og blødningssymptomer $(2,19)$, ellers ved alvorlig blødninger uansett platetall.

Pasientene kan grovt deles inn i tre behandlingskategorier - de med aktiv blødning, der behandling er obligatorisk, dernest de potensielt behandlingstrengende, som omfatter dem med blodplatetall $<30 \cdot 10^{9} / 1$ og særskilt dem med blodplatetall $<10 \cdot 10^{9} / 1$, og til sist de ikke-behandlingstrengende, som har blodplatetall $>30 \cdot 10^{9} / 1$ og er uten blødningsproblemer.

Figur 2 gir en oversikt over aktuelle behandlingsalternativer $\mathrm{i}$ de forskjellige sykdomsfasene.

\section{Førstelinjebehandling}

Kortikosteroider. Prednisolon er førstelinjebehandling. Vanligvis gis det $1-2 \mathrm{mg} / \mathrm{kg} / \mathrm{d}$ i $2-4$ uker. $75 \%$ av pasientene responderer med trombocyttstigning i løpet av 1-2 uker. Ved oppnådd respons startes nedtrapping i individuelt tempo. Kun 10-15\% oppnår langvarig respons etter behandling med kortikosteroider (18).

Man bør unngå langvarig behandling med kortikosteroider i store doser fordi det er høy risiko for alvorlige og dødelige infeksjoner ved behandlingsvarighet utover to måneder (1). Høydosebehandling med deksametason (40 mg/d i fire dager) er rapportert å gi god og rask respons $(85 \%)$ og er et alternativ til prednisolon (20). Det er vist at gjentatt behandling, opptil seks kurer med 2-4 ukers intervall, gir vedvarende respons, med trombocyttstigning til $>50 \cdot 10^{9} / 1$ hos $70 \%$ (21).

Anti-D-immunoglobulin. Anti-D-immunglobulin anvendes i noen land (ikke i Norge) som et alternativ til splenektomi hos Rhpositive pasienter. Det gir økt blodplatetall hos $70 \%$ av Rh-positive som ikke har gjennomgått splenektomi (1). WinRho Anti-D kan gis intravenøst over noen minutter, og effekten er sammenliknbar med intravenøst immunglobulin, men effekten varer betydelig lenger. WinRho Anti-D er det eneste antiD-preparat som har immunologisk trombocytopeni som indikasjon. Det er ikke registrert i Norge. Grunnet utilstrekkelig sikkerhetsdokumentasjon er det nylig blitt fjernet fra det europeiske markedet (14).

Alvorlige blødninger. Pasienter med livstruende blødninger trenger akuttbehandling. I tillegg til direkte håndtering av blødningskilden er følgende alternativer aktuelle og kan gis i tillegg til kortikosteroider: Intravenøst immunglobulin $1 \mathrm{~g} / \mathrm{kg}$, som gjentas neste dag hvis platetallet fortsatt er $<50 \cdot 10^{9} / 1$. Dette har vist seg å være effektivt - platetallet stiger raskt og det er initial respons hos $80 \%$ av pasientene. Imidlertid er responsen kortvarig, og platetallet er vanligvis tilbake til utgangsnivået etter 3-4 uker (1). Bruken av intravenøst immunglobulin er derfor ofte begrenset til akuttbehandling ved livstruende blødninger og før kirurgi der man ikke kan vente på effekten av annen behandling. Det tolereres vanligvis godt, men bivirkninger som allergiske reaksjoner, nyresvikt, hodepine og aseptisk meningitt er rapportert. Som et hjelpemiddel for å plukke ut hvilke pasienter som kan ha nytte av midlet utviklet Khellaf og medarbeidere en blødningsskår (e-tab 2) (22). De viste at behandling med intravenøst immunglobulin kan begrenses til pasienter med skår $>8$ (22).

Blodplatetransfusjoner gir rask, men kortvarig effekt, og må vurderes ved alvorlige og livstruende blødninger. Det er vist at transfusjon fører til at platetallet øker med over $20 \cdot 10^{9} / 1$ hos $42 \%$ av pasientene med blødning (23).

\section{Annenlinjebehandling}

Fordi de fleste vil få tilbakefall under nedtrapping eller ved seponering av kortikosteroider, er det ofte nødvendig med annenlinjebehandling. Hovedmålet med denne er å oppnå et platetall hvor man unngår blødninger. Valget av annenlinjebehandling må individualiseres ut fra blødningsrisiko, komorbiditet og muligheten for å gjennomføre behandlingen (14).

Splenektomi. Dette regnes fortsatt som standard annenlinjebehandling. Splenektomi er effektivt - det er komplett responsrate med fullstendig normalisering av blodplatetall på

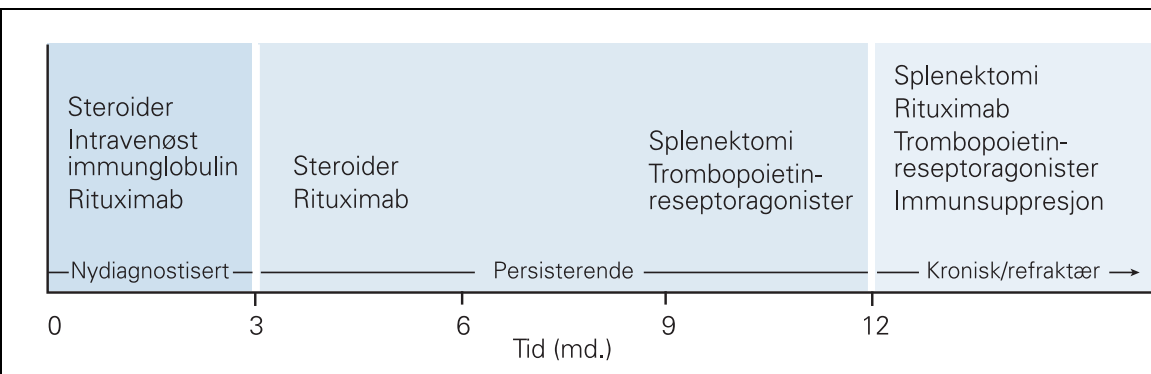

Figur 2 Behandlingsalternativer ved immunologisk trombocytopeni i forskjellige sykdomsfaser. Rituximab er ikke godkjent for bruk ved sykdommen, men slik bruk anbefales i kliniske studier. Trombopoietinreseptoragonister er godkjent i Norge for behandling av refraktær sykdom eller som alternativ til splenektomi dersom dette er kontraindisert
$70 \%$, og responsen varer i minst fem år hos omtrent to tredeler av pasientene (24). Fordi spontane remisjoner ses hos inntil $10 \%$ av pasientene, anbefales splenektomi først 6-12 måneder etter diagnosetidspunktet (1).

Splenektomi er forbundet med tidlige komplikasjoner. Den postoperative dødeligheten og hyppigheten av øvrige komplikasjoner etter laparoskopisk splenektomi er henholdsvis $0,2 \%$ og $10 \%$ (24). For pasienten er det dessuten livslang risiko for alvorlige infeksjoner med kapselkledde bakterier, spesielt pneumokokkinfeksjoner. Derfor anbefales det at pasientene pneumokokkvaksineres.

Rituximab. Rituximab, et anti-CD20-antistoff ( $375 \mathrm{mg} / \mathrm{m}^{2}$ ukentlig i fire uker), har i studier vist en responsrate på 40-60\% (25). Responsen inntreffer vanligvis 3-8 uker etter første infusjon. Langvarig remisjon ses hos $15-20 \%$. Tilsvarende responsrate er også vist med lavere dose: $100 \mathrm{mg}$ ukentlig $\mathrm{i}$ fire uker (26). Det er bred enighet om at rituximab er et godt behandlingsalternativ ved refraktær immunologisk trombocytopeni $(13,25)$. Derimot diskuteres det om man bør forsøke med dette midlet før splenektomi. Godeau og medarbeidere viste nylig at 20 av 60 pasienter (33\%) som var henvist til splenektomi, men i stedet ble behandlet med rituximab, hadde persisterende respons etter to år (27). Splenektomi ble unngått hos 58 \%.

Det er økt bruk av rituximab før splenektomi i den vestlige verden, men det er uavklart om midlet reduserer behovet eller bare utsetter tidspunktet for inngrepet (18). For å avklare dette må det gjøres randomiserte og placebokontrollerte studier. Vi anbefaler å inkludere pasienter som trenger annenlinjebehandling i den pågående randomiserte, placebokontrollerte RITP-studien (NCT00344149) (28).

Rituximab har en akseptabel bivirkningsprofil. Forbigående infusjonsrelaterte bivirkninger som frysninger, feber, blodtrykksfall og dyspné er ganske vanlig.

Trombopoietinreseptoragonister. Romiplostim og eltrombopag er nylig lansert som behandlingsalternativer ved immunologisk trombocytopeni. Disse medikamentene virker som trombopoietinreseptoragonister med effekt på linje med endogent trombopoietin, men ingen av medikamentene deler aminosyresekvens med nativt trombopoietin (29).

Romiplostim er et peptid og administreres som ukentlige subkutane injeksjoner. Startdosen er $1 \mu \mathrm{g} / \mathrm{kg}$. Dosen økes med 1-2 $\mu \mathrm{g} /$ $\mathrm{kg} / \mathrm{uke}$ inntil man oppnår en stigning i blodplatetall til $>50 \cdot 10^{9} / 1$. Effekten kan ses allerede den første uken.

I en studie med 63 splenektomerte og 62 ikke-splenektomerte pasienter med immunologisk trombocytopeni oppnådde 16 av 42 splenektomerte (38\%) i romiplostimarmen versus ingen av de $21 \mathrm{i}$ placebogruppen et varig blodplatetall på $>50 \cdot 10^{9} / 1$, det samme var tilfellet for 25 av 41 ikke-splenektomerte $(56 \%)$ i romiplostimgruppen versus én av 21 i placebogruppen (5\%) (30). Total- 
responsen (enten varig eller forbigående trombocyttstigning) etter romiplostim var $88 \%$ for de ikke-splenektomerte og $79 \%$ for de splenektomerte. $87 \%$ av dem som fikk romiplostim kunne redusere eller avvikle annen behandling for immunologisk trombocytopeni. Hodepine var vanligste bivirkning og forekom hos en tredel. Mindre hyppige bivirkninger var muskelsmerter, svimmelhet og abdominalsmerter (30). Alvorlige bivirkninger som trombose og blødning ble rapportert hos $9 \%$ (31). Retikulinfibrose i beinmargen ble påvist hos en del.

Eltrombopag er et lite molekyl som tas peroralt. En studie med midlet $(25 \mathrm{mg}, 50 \mathrm{mg}$ og $75 \mathrm{mg}$ ) versus placebo ved trombocyttall $<30 \cdot 10^{9} / 1$ viste en responsrate (trombocyttall $>50 \cdot 10^{9} / 1$ etter seks ukers behandling) på henholdsvis $28 \%, 70 \%, 81 \%$ og $11 \%$ (32). I en annen studie hevet eltrombopag (50-75 mg daglig) blodplatetallet til $>50 \cdot 10^{9} / 1$ etter seks ukers behandling hos $59 \%$ av pasientene, sammenliknet med $16 \%$ i placebogruppen. Kvalme og oppkast var de hyppigst rapporterte bivirkningene (33).

Romiplostim og eltrombopag er godkjent i Norge for behandling av refraktær immunologisk trombocytopeni etter splenektomi eller som alternativ til splenektomi dersom dette er kontraindisert. Begge medikamenter ser ut til å ha en gunstig kortsiktig bivirkningsprofil. Risikoen for senbivirkninger er derimot ukjent, og det er uklart hvilken betydning retikulinfibrose i beinmargen vil kunne ha, i likhet med katarakt, som er rapportert ved eltrombopagbehandling.

\section{Refraktær immunologisk trombocytopeni}

$10-20 \%$ av pasientene vil utvikle behandlingsrefraktær sykdom (tab 1). Det er viktig å utelukke ikke-immunologiske årsaker til trombocytopenien før sykdommen oppfattes som refraktær. Myelodysplastisk syndrom og aplastisk anemi er viktige differensialdiagnoser som krever helt annen behandling. Trombopoietinreseptoragonister har i randomiserte studier vist høy responsrate og vil være et godt alternativ ved refraktær immunologisk trombocytopeni.

Andre medikamenter som vinkristin, cyklofosfamid, azatioprin, dapson, danazol, mykofenolatmofetil og ciklosporin har vist en viss effekt ved immunologisk trombocytopeni. Imidlertid er responsratene etter behandling med disse medikamentene lave $(30-40 \%)$, og det er ofte uttalte bivirkninger. Danazol og mykofenolatmofetil har vist høyere responsrater, på henholdsvis $60 \% \mathrm{og}$ $80 \%$, i noen studier (14).

Immunologisk trombocytopeni og graviditet Initial behandling av gravide med immunologisk trombocytopeni er som behandlingen av voksne ellers. Gjennom de første to trimestrene bør behandling initieres dersom det oppstår symptomatisk blødning eller blodplatetallet er $<30 \cdot 10^{9} / 1$. Kortikosteroider, eventuelt sammen med intravenøst im- munglobulin, er førstelinjebehandling. Rituximab og trombopoietinreseptoragonister bør unngås. Ved svikt i førstelinjebehandlingen utføres splenektomi lettest $\mathrm{i}$ annet trimester (14). Forløsningsmetoden avgjøres av den obstetriske situasjonen.

IgG-antistoffer krysser placenta og kan indusere føtal trombocytopeni. Imidlertid har ca. $90 \%$ av barn født av mødre med immunologisk trombocytopeni et platetall $>50 \cdot 10^{9} / 1$. Alvorlige intrakraniale blødninger er sjeldent $(<1 \%)$ (34). Platetallet hos nyfødte med mødre med immunologisk trombocytopeni er uforutsigbart og korrelerer ikke med platetall eller behandlingsrespons hos mor.

\section{Konklusjon}

Frem til nå har man i behandlingsstrategien ved immunologisk trombocytopeni lagt hovedvekten på å bedre trombocyttlevetiden enten ved medikamentell immunsuppresjon eller splenektomi. Ny kunnskap om patofysiologiske mekanismer har åpnet for tiltak for å øke blodplateproduksjonen. Det har vist seg at både rituximab og trombopoietinreseptoragonister er effektive behandlingsalternativer ved immunologisk trombocytopeni.

Oppgitte interessekonflikter: Alle forfatterne har mottatt støtte til forskning fra Roche og honorar for foredrag fra Amgen, som leverer henholdsvis ritu-

ximab og romiplostim.

e-tab 2 finnes i artikkelen på www.tidsskriftet.no

\section{Litteratur}

1. Godeau B, Provan D, Bussel J. Immune thrombocytopenic purpura in adults. Curr Opin Hemato 2007; 14: 535-56

2. Rodeghiero F, Stasi R, Gernsheimer T et al. Standardization of terminology definitions and outcome criteria in immune thrombocytopenic purpura of adults and children: report from an international working group. Blood 2009; 113: 2386-93.

3. Frederiksen $\mathrm{H}$, Schmidt $\mathrm{K}$. The incidence of idiopathic thrombocytopenic purpura in adults increases with age. Blood 1999; 94: 909-13.

4. Schoonen WM, Kucera G, Coalson J et al. Epidemiology of immune thrombocytopenic purpura in the General Practice Research Database. Br J Haematol 2009: 145: 235-44.

5. Segal JB, Powe NR. Prevalence of immune thrombocytopenia: analyses of administrative data. J Thromb Haemost 2006; 4: 2377-83.

6. Provan D. Characteristics of immune thrombocytopenic purpura: a guide for clinical practice. Eur J Haematol Suppl 2009; 71: 8-12

7. Semple JW. Immune pathophysiology of autoimmune thrombocytopenic purpura. Blood Rev 2002: 16: 9-12.

8. Nugent D, McMillan R, Nichol JL et al. Pathogenesis of chronic immune thrombocytopenia: increased platelet destruction and/or decreased platelet production. Br J Haematol 2009: 146: 585-96.

9. Olsson B, Andersson PO, Jernås M et al. T-cellmediated cytotoxicity toward platelets in chronic idiopathic thrombocytopenic purpura. Nat Med 2003; 9: 1123-4

10. Olsson B, Ridell B, Carlsson L et al. Recruitment of $T$ cells into bone marrow of ITP patients possibly due to elevated expression of VLA- 4 and CX3CR1. Blood 2008; 112: 1078-84

11. Houwerzijl EJ, Blom NR, van der Want JJ et al. Ultrastructural study shows morphologic features of apoptosis and para-apoptosis in megakaryocytes from patients with idiopathic thrombocytopenic purpura. Blood 2004; 103: 500-6.

12. Kaushansky K. Thrombopoietin: accumulating evidence for an important biological effect on the hematopoietic stem cell. Ann N Y Acad Sci 2003: 996: $39-43$
13. Stasi R, Evangelista ML, Stipa E et al. Idiopathic thrombocytopenic purpura: current concepts in pathophysiology and management. Thromb Haemost 2008; 99: 4-13.

14. Provan D. Stasi R, Newland AC et al. International consensus report on the investigation and management of primary immune thrombocytopenia. Blood 2010; 115: 168-86.

15. Cohen YC, Djulbegovic B, Shamai-Lubovitz 0 et al. The bleeding risk and natural history of idiopathic thrombocytopenic purpura in patients with persistent low platelet counts. Arch Intern Med 2000; 160: $1630-8$.

16. McMillan R, Bussel JB, George JN et al. Selfreported health-related quality of life in adults with chronic immune thrombocytopenic purpura. Am J Hematol 2008; 83: $150-4$

17. Mathias SD, Gao SK, Miller KL et al Impact of chronic Immune Thrombocytopenic Purpura (ITP) on health-related quality of life: a conceptual model starting with the patient perspective. Health Qual Life Outcomes 2008; 6: 13.

18. Stasi R. Immune thrombocytopenic purpura: the treatment paradigm. Eur J Haematol Suppl 2009 71: 13-9

19. George JN, Woolf SH, Raskob GE et al. Idiopathic thrombocytopenic purpura: a practice guideline developed by explicit methods for the American Society of Hematology. Blood 1996; 88: 3-40.

20. Cheng Y, Wong RS, Soo YO et al. Initial treatment of immune thrombocytopenic purpura with high-dose dexamethasone. N Engl J Med 2003; 349: 831-6.

21. Mazzucconi MG Fazi P Bernasconi S et al. Therapy with high-dose dexamethasone (HD-DXM) in previously untreated patients affected by idiopathic thrombocytopenic purpura: a GIMEMA experience. Blood 2007: 109: 1401-7.

22. Khellaf M, Michel M, Schaeffer A et al. Assessmen of a therapeutic strategy for adults with severe autoimmune thrombocytopenic purpura based on a bleeding score rather than platelet count. Haematologica 2005: 90: 829-32.

23. Carr JM, Kruskall MS, Kaye JA et al. Efficacy of platelet transfusions in immune thrombocytopenia. Am J Med 1986; 80: 1051-4.

24. Kojouri K, Vesely SK, Terrell DR et al. Splenectomy for adult patients with idiopathic thrombocytopenic purpura: a systematic review to assess long-term platelet count responses, prediction of response, and surgical complications. Blood 2004; 104: 2623-34.

25. Arnold DM, Dentali F. Crowther MA et al. Systematic review: efficacy and safety of rituximab for adults with idiopathic thrombocytopenic purpura. Ann Intern Med 2007; 146: 25-33.

26. Provan D, Butler T, Evangelista ML et al. Activity and safety profile of low-dose rituximab for the treatment of autoimmune cytopenias in adults. Haematologica 2007; 92: 1695-8.

27. Godeau B, Porcher R, Fain 0 et al. Rituximab efficacy and safety in adult splenectomy candidates with chronic immune thrombocytopenic purpura: results of a prospective multicenter phase 2 study. Blood 2008; 112: 999-1004.

28. ClinicalTrials.gov. www. clinicaltrials.gov/ (15.9.2010).

29. Kuter DJ. New thrombopoietic growth factors. Blood 2007; 109: 4607-16.

30. Kuter DJ, Bussel JB, Lyons RM et al. Efficacy of romiplostim in patients with chronic immune thrombocytopenic purpura: a double-blind random ised controlled trial. Lancet 2008 : 371: 395-403.

31. Bussel JB, Kuter DJ, Pullarkat V et al. Safety and efficacy of long-term treatment with romiplostim in thrombocytopenic patients with chronic ITP. Blood 2009: 113: 2161-71.

32. Bussel JB, Cheng G, Saleh MN et al. Eltrombopag for the treatment of chronic idiopathic thrombocy topenic purpura. N Engl J Med 2007; 357: 2237-47

33. Bussel JB, Provan D, Shamsi T et al. Effect of eltrombopag on platelet counts and bleeding during treatment of chronic idiopathic thrombocytopenic purpura: a randomised, double-blind, placebo-controlled trial. Lancet 2009; 373: 641-8.

34. Burrows RF, Kelton JG. Pregnancy in patients with idiopathic thrombocytopenic purpura: assessing the risks for the infant at delivery. Obstet Gynecol Surv 1993; 48: 781-8.

Manuskriptet ble mottatt 21.9. 2009 og godkjent 1.7. 2010. Medisinsk redaktør Trine B. Haugen. 